\title{
Brevundimonas lenta sp. nov., isolated from soil
}

Correspondence

Jung-Hoon Yoon

jhyoon@kribb.re.kr

\author{
Jung-Hoon Yoon, So-Jung Kang, Jung-Sook Lee, Hyun Woo Oh \\ and Tae-Kwang Oh
}

Korea Research Institute of Bioscience and Biotechnology (KRIBB), PO Box 115, Yusong, Taejon, Korea

\begin{abstract}
A Gram-negative, rod-shaped, Brevundimonas-like bacterial strain, DS-18 ${ }^{\top}$, was isolated from soil in Dokdo, Korea, and its exact taxonomic position was investigated by using a polyphasic approach. Strain DS-18 $8^{\top}$ grew optimally at $\mathrm{pH} 6.5-7.0$ and $25{ }^{\circ} \mathrm{C}$ without $\mathrm{NaCl}$. Phylogenetic analysis based on $16 \mathrm{~S}$ rRNA gene sequences showed that strain DS-18 ${ }^{\top}$ belonged to the genus Brevundimonas. Strain DS-18 ${ }^{\top}$ contained $\mathrm{Q}-10$ as the predominant ubiquinone and $\mathrm{C}_{18: 1} \omega 7 \mathrm{c}$ and $\mathrm{C}_{16: 0}$ as the major fatty acids. The DNA G+C content was $68.7 \mathrm{~mol} \%$. Strain DS-18 ${ }^{\top}$ exhibited levels of $16 \mathrm{~S}$ rRNA gene sequence similarity of $96.3-98.7 \%$ to the type strains of Brevundimonas species and Mycoplana bullata. Mean DNA-DNA relatedness values between strain DS-18 ${ }^{\top}$ and the type strains of phylogenetically related Brevundimonas species and M. bullata were in the range 15-32\%. Strain DS-18 ${ }^{\top}$ differed from Brevundimonas species and $M$. bullata in several phenotypic characteristics. On the basis of phenotypic, phylogenetic and genetic data, strain DS-18 ${ }^{\top}$ represents a novel species of the genus Brevundimonas, for which the name Brevundimonas lenta sp. nov. is proposed. The type strain is DS-18 ${ }^{\top}$ (=KCTC $12871^{\top}$ $=J C M 14602^{\top}$ ).
\end{abstract}

The genus Brevundimonas, which was proposed by reclassification of two Pseudomonas species by Segers et al. (1994), currently comprises 12 species with validly published names: Brevundimonas diminuta and B. vesicularis (Segers et al., 1994), B. alba, B. aurantiaca, B. bacteroides, B. intermedia, B. subvibrioides and B. variabilis (Abraham et al., 1999), B. nasdae (Li et al., 2004), B. mediterranea (Fritz et al., 2005), B. kwangchunensis (Yoon et al., 2006a) and B. terrae (Yoon et al., 2006b). Here, the taxonomic characterization is reported of a Brevundimonas-like bacterial strain, DS- $18^{\mathrm{T}}$, which was isolated from a soil sample from Dokdo in Korea.

Strain DS $-18^{\mathrm{T}}$ was isolated by the standard dilution plating technique at $25^{\circ} \mathrm{C}$ on $10 \times$ diluted nutrient agar (NA; Difco). The type strains of eight Brevundimonas species and Mycoplana bullata were used as reference strains for DNADNA hybridization: B. alba LMG $18360^{\mathrm{T}}$, B. aurantiaca LMG $18359^{\mathrm{T}}$, B. diminuta LMG $2089^{\mathrm{T}}$, B. intermedia LMG $18361^{\mathrm{T}}, B$. subvibrioides LMG $14903^{\mathrm{T}}$ and B. variabilis LMG $18362^{\mathrm{T}}$ were obtained from the Laboratorium voor Microbiologie Universiteit Gent (LMG), Gent, Belgium; $B$. kwangchunensis KSL-102 ${ }^{\mathrm{T}}$ and B. terrae KSL-145 ${ }^{\mathrm{T}}$ were obtained from the studies of Yoon et al. (2006a, b); and

The GenBank/EMBL/DDBJ accession number for the 16S rRNA gene sequence of strain DS-18 ${ }^{\top}$ is EF363713.

Differential phenotypic characteristics of Brevundimonas lenta sp. nov. and related species are available as supplementary material with the online version of this paper.
M. bullata DSM $7126^{\mathrm{T}}$ was obtained from the Deutsche Sammlung von Mikroorganismen und Zellkulturen (DSMZ), Braunschweig, Germany. The morphological, physiological and biochemical characteristics of strain DS- $18^{\mathrm{T}}$ were investigated using routine cultivation on $\mathrm{NA}$ at $25{ }^{\circ} \mathrm{C}$. Cell morphology was examined by light microscopy (Nikon E600) and transmission electron microscopy. Flagellation was determined by using a Philips CM-20 transmission electron microscope with cells from exponentially growing cultures: for this purpose, cells were negatively stained with $1 \%(\mathrm{w} / \mathrm{v})$ phosphotungstic acid and the grids were examined after being air-dried. The Gram reaction was determined using the bioMérieux Gram stain kit according to the manufacturer's instructions. Growth at various temperatures $\left(4-40{ }^{\circ} \mathrm{C}\right)$ was measured on NA. Growth in the absence of $\mathrm{NaCl}$ was investigated in trypticase soy broth prepared according to the formula of the Difco medium except that $\mathrm{NaCl}$ was excluded. The $\mathrm{pH}$ range for growth was determined in nutrient broth (NB; Difco) that was adjusted to various $\mathrm{pH}$ values (initial $\mathrm{pH} 4.5-10.5$ at intervals of $0.5 \mathrm{pH}$ units) prior to sterilization by the addition of $\mathrm{HCl}$ or $\mathrm{Na}_{2} \mathrm{CO}_{3}$. Growth under anaerobic conditions was determined after incubation in an anaerobic chamber on NA and on NA supplemented with nitrate, both of which had been prepared anaerobically using nitrogen. Catalase and oxidase activities and hydrolysis of casein, gelatin, hypoxanthine, starch, Tweens 20, 40, 60 and 80, tyrosine, urea and xanthine were determined as described by Cowan \& Steel (1965). Hydrolysis of aesculin and nitrate reduction were studied as described 
Table 1. Biolog assimilation data for strain DS-18 ${ }^{\top}$, several Brevundimonas species and M. bullata

Strains: 1 , DS- $18^{\mathrm{T}}$ (B. lenta sp. nov.); 2, B. diminuta LMG $2089^{\mathrm{T}} ; 3$, B. vesicularis $\mathrm{LMG} 2350^{\mathrm{T}} ; 4$, B. aurantiaca LMG $18359^{\mathrm{T}}$; 5, B. bacteroides LMG $15096^{\mathrm{T}}$; 6, B. intermedia LMG $18361^{\mathrm{T}}$; 7, B. subvibrioides LMG $14903^{\mathrm{T}}$;

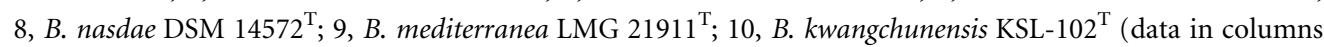
2-10 taken from Yoon et al., 2006a); 11, B. terrae KSL-145 ${ }^{\mathrm{T}}$ (Yoon et al., 2006b); 12, M. bullata DSM $7126^{\mathrm{T}}$ (data from this study). W, Weak. All strains are negative for assimilation of $N$-acetyl-D-galactosamine, adonitol, L-arabinose, D-arabitol, $i$-erythritol, L-fucose, myo-inositol, lactulose, D-mannitol, methyl $\beta$-D-glucoside, D-psicose, D-raffinose, D-sorbitol, sucrose, xylitol, cis-aconitic acid, citric acid, formic acid, D-galactonic acid lactone, D-galacturonic acid, D-gluconic acid, D-glucosaminic acid, D-glucuronic acid, $\gamma$-hydroxybutyric acid, p-hydroxyphenylacetic acid, itaconic acid, malonic acid, quinic acid, D-saccharic acid, sebacic acid, succinamic acid, glucuronamide, L-ornithine, L-phenylalanine, L-pyroglutamic acid, D-serine, DL-carnitine, $\gamma$-aminobutyric acid, urocanic acid, inosine, uridine, thymidine, phenyl ethylamine, putrescine, 2-aminoethanol, 2,3butanediol, glycerol and DL- $\alpha$-glycerol phosphate. All strains are positive for assimilation of L-glutamic acid.

\begin{tabular}{|c|c|c|c|c|c|c|c|c|c|c|c|c|}
\hline Substrate & 1 & 2 & 3 & 4 & 5 & 6 & 7 & 8 & 9 & 10 & 11 & 12 \\
\hline$\alpha$-Cyclodextrin & - & - & + & + & + & + & - & + & + & + & - & - \\
\hline Dextrin & + & - & + & + & + & + & + & + & + & + & - & + \\
\hline Glycogen & - & - & - & - & - & + & - & - & + & + & - & - \\
\hline Tween 40 & - & + & + & + & - & - & - & + & + & - & + & - \\
\hline Tween 80 & - & - & + & + & - & - & - & + & + & - & + & - \\
\hline$N$-Acetyl-D-glucosamine & - & - & - & - & - & - & - & + & - & - & - & - \\
\hline Cellobiose & - & - & + & + & + & + & + & + & + & + & - & - \\
\hline D-Fructose & - & - & - & - & - & - & - & - & - & + & - & - \\
\hline D-Galactose & - & - & + & - & - & + & - & + & - & - & - & - \\
\hline Gentiobiose & - & - & - & - & - & + & - & + & + & $\mathrm{w}$ & - & - \\
\hline D-Glucose & - & - & + & + & + & + & + & + & + & + & - & + \\
\hline D-Lactose & - & - & - & - & - & + & - & - & - & - & - & - \\
\hline Maltose & - & - & + & + & + & + & - & + & + & + & - & - \\
\hline D-Mannose & - & - & - & - & - & + & - & - & - & + & - & - \\
\hline D-Melibiose & - & - & - & - & - & + & - & + & - & - & - & - \\
\hline L-Rhamnose & - & - & - & - & - & - & - & + & - & - & - & - \\
\hline Trehalose & - & - & - & - & - & - & - & - & - & + & - & - \\
\hline Turanose & - & - & - & - & - & - & - & - & - & + & - & $\mathrm{w}$ \\
\hline Methylpyruvate & - & + & + & + & - & - & - & + & + & + & + & + \\
\hline Monomethyl succinate & - & - & - & - & - & - & - & + & - & - & - & - \\
\hline Acetic acid & - & + & + & - & - & + & - & + & + & - & - & - \\
\hline$\alpha$-Hydroxybutyric acid & - & - & + & - & - & - & - & + & - & - & - & - \\
\hline$\beta$-Hydroxybutyric acid & - & + & + & + & + & + & - & + & + & + & + & + \\
\hline$\alpha$-Ketobutyric acid & - & - & - & - & - & - & - & + & - & - & - & + \\
\hline$\alpha$-Ketoglutaric acid & + & - & - & - & - & - & - & - & - & - & - & - \\
\hline$\alpha$-Ketovaleric acid & - & + & - & - & - & - & - & + & - & - & - & - \\
\hline DL-Lactic acid & - & - & + & - & - & - & - & + & - & - & - & - \\
\hline Propionic acid & - & - & - & - & - & - & - & + & - & - & + & - \\
\hline Succinic acid & - & - & + & - & - & + & - & + & + & + & - & - \\
\hline Bromosuccinic acid & - & - & + & - & - & - & - & - & - & - & - & - \\
\hline Alaninamide & - & + & + & - & - & + & + & + & + & + & + & + \\
\hline D-Alanine & - & + & + & - & - & - & - & + & - & - & + & + \\
\hline L-Alanine & - & + & + & - & - & + & - & + & + & + & + & + \\
\hline L-Alanyl glycine & - & + & + & - & - & + & - & + & + & + & + & + \\
\hline L-Asparagine & - & + & - & - & - & - & - & + & - & + & + & + \\
\hline L-Aspartic acid & - & + & - & - & - & - & - & + & - & + & + & + \\
\hline Glycyl L-aspartic acid & - & + & - & - & - & - & - & + & - & - & + & + \\
\hline Glycyl L-glutamic acid & - & + & + & + & - & + & + & + & + & + & + & + \\
\hline L-Histidine & - & - & - & - & - & - & - & - & - & - & $\mathrm{w}$ & - \\
\hline Hydroxy L-proline & - & + & - & - & - & - & - & - & - & - & + & - \\
\hline
\end{tabular}


Table 1. cont.

\begin{tabular}{|lcccccccccccc|}
\hline Substrate & $\mathbf{1}$ & $\mathbf{2}$ & $\mathbf{3}$ & $\mathbf{4}$ & $\mathbf{5}$ & $\mathbf{6}$ & $\mathbf{7}$ & $\mathbf{8}$ & $\mathbf{9}$ & $\mathbf{1 0}$ & $\mathbf{1 1}$ & $\mathbf{1 2}$ \\
\hline L-Leucine & - & - & - & - & - & - & - & + & - & - & + & - \\
L-Proline & + & + & + & - & - & - & - & + & - & + & + & + \\
L-Serine & - & + & + & - & - & - & - & + & + & + & + & + \\
L-Threonine & - & - & + & - & - & - & - & + & + & + & + & + \\
Glucose 1-phosphate & - & - & + & - & - & - & - & - & - & + & - & + \\
Glucose 6-phosphate & - & - & - & - & - & - & - & - & - & + & - & + \\
\hline
\end{tabular}

previously (Lanyi, 1987). Assimilation of various substrates was determined by using the Biolog GN2 MicroPlate assay as recommended by the manufacturer. Sensitivity to antibiotics was tested on NA plates using antibiotic discs containing: polymyxin B, $100 \mathrm{U}$; streptomycin, $50 \mu \mathrm{g}$; penicillin G, $20 \mathrm{U}$; chloramphenicol, $100 \mu \mathrm{g}$; ampicillin, $10 \mu \mathrm{g}$; cephalothin, $30 \mu \mathrm{g}$; gentamicin, $30 \mu \mathrm{g}$; novobiocin, $5 \mu \mathrm{g}$; tetracycline, $30 \mu \mathrm{g}$; kanamycin, $30 \mu \mathrm{g}$; lincomycin, $15 \mu \mathrm{g}$; oleandomycin, $15 \mu \mathrm{g}$; neomycin, $30 \mu \mathrm{g}$; and carbenicillin, $100 \mu \mathrm{g}$. Other physiological and biochemical properties were investigated using the API 20E and API ZYM systems (bioMérieux).

Cell biomass for DNA extraction and isoprenoid quinone analysis was obtained from cultures grown in NB at $25{ }^{\circ} \mathrm{C}$. Chromosomal DNA was isolated and purified according to the method described by Yoon et al. (1996), with the exception that RNase T1 was used in combination with RNase A to minimize contamination with RNA. The $16 \mathrm{~S}$ rRNA gene was amplified by PCR using two universal primers as described previously (Yoon et al., 1998). Sequencing of the amplified 16S rRNA gene and phylogenetic analysis were performed as described by Yoon et al. (2003). Isoprenoid quinones were extracted according to the method of Komagata \& Suzuki (1987) and analysed using reversed-phase HPLC and a YMC ODS-A $(250 \times$ $4.6 \mathrm{~mm}$ ) column. For fatty acid analysis, cell mass of strain DS- $18^{\mathrm{T}}$ was harvested from NA plates after incubation for 7 days at $25{ }^{\circ} \mathrm{C}$. Fatty acids were extracted and fatty acid methyl esters were prepared according to the standard protocol of the MIDI/Hewlett Packard Microbial Identification System (Sasser, 1990). The DNA G + C content was determined by the method of Tamaoka \& Komagata (1984) with a modification that DNA was hydrolysed and the resultant nucleotides were analysed by reversed-phase HPLC. DNA-DNA hybridization was performed fluorometrically by the method of Ezaki et al. (1989) using photobiotin-labelled DNA probes and microdilution wells. Hybridization was performed with five replications for each sample. The highest and lowest values obtained in each sample were excluded and the means of the remaining three values are quoted as DNA-DNA relatedness values.

Morphological, cultural, physiological and biochemical characteristics of strain DS- $18^{\mathrm{T}}$ are given in the species description, Table 1 and Supplementary Table S1 (available in IJSEM Online). The almost-complete 16S rRNA gene sequence of strain DS- $18^{\mathrm{T}}$ determined in this study comprised $1418 \mathrm{nt}$, representing approximately $96 \%$ of the Escherichia coli 16S rRNA gene sequence. 16S rRNA gene sequence analyses showed that strain $D S-18^{\mathrm{T}}$ was most closely affiliated with members of the genus Brevundimonas. In the phylogenetic tree based on the neighbourjoining algorithm, strain DS- $18^{\mathrm{T}}$ fell within the cluster comprising Brevundimonas species and M. bullata (Fig. 1). Strain DS- $18^{\mathrm{T}}$ exhibited 16S rRNA gene sequence similarity values of 96.3-98.7\% to the type strains of Brevundimonas species and M. bullata, and less than $95.1 \%$ to other species included in the phylogenetic analysis (Fig. 1).

Chemotaxonomic properties confirm the phylogenetic affiliation of strain DS- $18^{\mathrm{T}}$ to the genus Brevundimonas. The predominant isoprenoid quinone detected in strain DS- $18^{\mathrm{T}}$ was ubiquinone-10 (Q-10), at a peak area ratio of approximately $84 \%$; a significant amount of Q-8 (approx.

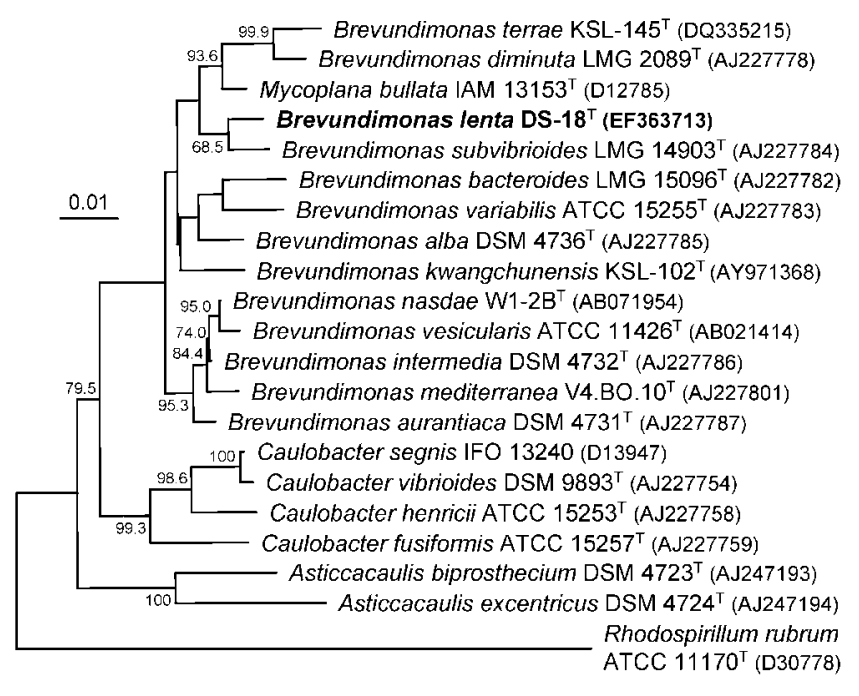

Fig. 1. Neighbour-joining phylogenetic tree based on $16 \mathrm{~S}$ rRNA gene sequences showing the positions of strain DS-18 ${ }^{\top}$, Brevundimonas species and some other related taxa (GenBank accession numbers are given in parentheses). Bootstrap values (expressed as percentages of 1000 replications) $>50 \%$ are shown at branch points. Rhodospirillum rubrum ATCC $11170^{\top}$ was used as an outgroup. Bar, 0.01 substitutions per nucleotide position. 
$13 \%)$ was also present. Q-10 has been reported as the predominant ubiquinone in Brevundimonas species (Segers et al., 1994; Abraham et al., 1999; Li et al., 2004; Fritz et al., 2005; Yoon et al., 2006a, b). Strain DS- $18^{\mathrm{T}}$ had a cellular fatty acid profile that contained large amounts of unsaturated, straight-chain and 11-methyl fatty acids; the major fatty acids ( $>10 \%$ total fatty acids) were $\mathrm{C}_{18: 1} \omega 7 \mathrm{c}$ and $\mathrm{C}_{16: 0}$ (Table 2). This fatty acid profile was similar to those of Brevundimonas species (Table 2). The DNA G $+\mathrm{C}$ content of strain DS- $18^{\mathrm{T}}$ was $68.7 \mathrm{~mol} \%$.

Strain DS- $18^{\mathrm{T}}$ exhibited mean DNA-DNA relatedness levels of $15-32 \%$ to the type strains of B. alba $(17 \%)$, B. aurantiaca $(15 \%), B$. diminuta $(17 \%), B$. intermedia (22\%), B. kwangchunensis (32\%), B. subvibrioides (30\%), B. terrae (18\%), B. variabilis (21\%) and M. bullata (27\%), all of which showed 16S rRNA gene sequence similarity values greater than $97 \%$ to strain DS- $18^{\mathrm{T}}$. Strain DS- $18^{\mathrm{T}}$ was distinguishable from recognized Brevundimonas species by differences in several phenotypic characteristics
(Table 1 and Supplementary Table S1). The phylogenetic distinctiveness, together with genetic data and differential phenotypic properties, were sufficient to allocate strain DS- $18^{\mathrm{T}}$ to a species that is separate from recognized Brevundimonas species and M. bullata (Wayne et al., 1987; Stackebrandt \& Goebel, 1994). Therefore, on the basis of the data presented, strain DS- $18^{\mathrm{T}}$ should be placed in the genus Brevundimonas as a representative of a novel species, for which the name Brevundimonas lenta sp. nov. is proposed.

\section{Description of Brevundimonas lenta sp. nov.}

Brevundimonas lenta (len'ta. L. fem. adj. lenta sticky, referring to sticky colonies).

Cells are Gram-negative rods $(0.3-0.5 \times 0.6-3.5 \mu \mathrm{m})$. Motile by means of a single polar flagellum. Colonies on NA are circular, convex, glistening, sticky, greyish-yellow in colour and $0.8-1.0 \mathrm{~mm}$ in diameter after 7 days incubation

Table 2. Cellular fatty acid compositions (\%) of strain $\mathrm{DS}-18^{\top}$ and the type strains of Brevundimonas species

Strains: 1 , strain DS- $18^{\mathrm{T}}$ (B. lenta sp. nov.); 2, B. terrae KSL-145 ${ }^{\mathrm{T}}$; 3, B. kwangchunensis $\mathrm{KSL}-102^{\mathrm{T}} ; 4$, B. diminuta LMG $2089^{\mathrm{T}} ; 5$, B. vesicularis LMG $2350^{\mathrm{T}} ; 6$, B. subvibrioides LMG $14903^{\mathrm{T}} ; 7$, B. bacteroides LMG $15096^{\mathrm{T}} ; 8$, B. aurantiaca LMG $18359^{\mathrm{T}} ; 9$, B. alba LMG $18360^{\mathrm{T}} ; 10$, B. variabilis LMG $18362^{\mathrm{T}}$ (data in columns 2-10 from Yoon et al., 2006b); 11, B. nasdae W1-2B ${ }^{\mathrm{T}} ; 12$, B. intermedia DSM 4732 ${ }^{\mathrm{T}}$ (data in columns 11 and 12 from Li et al., 2004); 13, B. mediterranea V4.BO.10 ${ }^{\mathrm{T}}$ (Fritz et al., 2005). -, Not detected. Fatty acids that represented $<0.5 \%$ in all strains were omitted.

\begin{tabular}{|c|c|c|c|c|c|c|c|c|c|c|c|c|c|}
\hline Fatty acid & 1 & 2 & 3 & 4 & 5 & 6 & 7 & 8 & 9 & 10 & 11 & 12 & 13 \\
\hline \multicolumn{14}{|l|}{ Straight-chain } \\
\hline $\mathrm{C}_{14: 0}$ & 2.0 & 5.2 & 2.6 & 0.5 & 3.1 & 3.6 & 3.7 & 3.3 & 1.2 & 2.9 & 1.7 & 1.5 & 0.6 \\
\hline $\mathrm{C}_{15: 0}$ & 5.8 & 5.2 & 6.4 & 8.4 & 3.5 & 6.4 & 3.4 & 2.6 & 4.7 & 7.8 & - & 2.8 & 5.4 \\
\hline$C_{16: 0}$ & 12.8 & 26.6 & 20.5 & 8.3 & 20.0 & 16.1 & 19.3 & 24.6 & 18.8 & 14.0 & 19.7 & 24.3 & 16.1 \\
\hline$C_{17: 0}$ & 2.2 & 1.3 & 1.8 & 7.5 & 1.2 & 3.1 & 1.5 & 2.8 & 2.7 & 4.9 & 3.8 & 1.6 & 6.1 \\
\hline $\mathrm{C}_{18: 0}$ & 0.3 & 0.4 & 0.4 & 0.2 & 0.4 & 0.5 & 0.4 & 1.3 & 0.7 & 0.6 & 1.0 & $<1.0$ & 0.9 \\
\hline \multicolumn{14}{|l|}{ Branched } \\
\hline \multicolumn{13}{|l|}{ Unsaturated } & - \\
\hline $\mathrm{C}_{15: 1} \omega 8 c$ & 0.2 & 0.5 & 0.3 & 2.6 & - & 0.2 & 0.1 & - & 0.4 & 0.6 & - & - & - \\
\hline $\mathrm{C}_{16: 1} \omega 9 \mathrm{c}$ & - & - & - & - & - & - & 0.4 & - & 1.9 & - & - & - & $8.4^{*}$ \\
\hline$C_{17: 1} \omega 6 c$ & 3.3 & 0.7 & 1.0 & 7.0 & 1.2 & 1.9 & 2.0 & 1.2 & 1.6 & 4.0 & 2.0 & 1.1 & 7.8 \\
\hline $\mathrm{C}_{17: 1} \omega 8 c$ & 7.3 & 1.4 & 3.1 & 12.8 & 2.1 & 4.4 & 3.4 & 1.6 & 6.0 & 8.9 & 2.6 & 2.0 & 9.9 \\
\hline $\mathrm{C}_{18: 1} \omega 7 c$ & 46.4 & 43.4 & 33.2 & 40.0 & 53.6 & 52.1 & 57.5 & 49.1 & 42.9 & 47.9 & - & - & $36.7^{*}$ \\
\hline $\mathrm{C}_{18: 1} \omega 9 \mathrm{c}$ & - & - & - & - & - & - & 0.2 & - & 1.3 & - & - & - & - \\
\hline \multicolumn{14}{|l|}{ Hydroxy } \\
\hline $\mathrm{C}_{12: 0} 3-\mathrm{OH}$ & 2.6 & 2.8 & 2.2 & 1.9 & 2.5 & 2.5 & 2.8 & 2.5 & 1.5 & 2.7 & 3.1 & 1.7 & 2.0 \\
\hline $\begin{array}{l}\mathrm{C}_{16: 0} 2-\mathrm{OH} \\
\text { Other }\end{array}$ & - & - & 0.3 & - & - & 0.9 & - & 0.4 & 0.3 & 0.3 & - & - & - \\
\hline 11-Methyl $\mathrm{C}_{18: 1} \omega 7 c$ & 8.9 & 7.2 & 22.1 & - & 4.9 & 1.2 & 0.4 & 7.9 & 6.3 & - & - & - & $4.2^{\star}$ \\
\hline cyclo $C_{19: 0} \omega 8 c$ & - & - & - & 6.6 & - & - & - & - & 4.8 & - & 7.6 & - & - \\
\hline \multicolumn{14}{|l|}{ Summed features $\dagger$} \\
\hline 1 & 0.6 & 0.2 & 0.3 & 1.2 & 0.2 & 0.5 & 0.2 & 0.2 & 0.8 & 0.9 & - & - & - \\
\hline 3 & 6.3 & 4.0 & 5.3 & 1.4 & 7.2 & 4.1 & 3.8 & 2.2 & 3.5 & 3.1 & 2.5 & 7.5 & - \\
\hline 7 & - & - & - & - & - & - & - & - & - & - & 51.6 & 49.4 & - \\
\hline
\end{tabular}

${ }^{\star}$ Referred to as $\mathrm{C}_{16: 1}, \mathrm{C}_{18: 1}$ and 11-methyl $\mathrm{C}_{18: 1} \omega 5 t$, respectively, by Fritz et al. (2005).

† Summed features represent groups of two or three fatty acids that cannot be separated by GLC with the MIDI system. Summed feature 1 contains iso- $\mathrm{C}_{15: 1}$ and/or $\mathrm{C}_{13: 0} 3-\mathrm{OH}$. Summed feature 3 contains $\mathrm{C}_{16: 1} \omega 7 c$ and/or iso- $\mathrm{C}_{15: 0} 2-\mathrm{OH}$. Summed feature 7 contains one or more of $\mathrm{C}_{18: 1} \omega 7 c$, $\mathrm{C}_{18: 1} \omega 9 t$ and $\mathrm{C}_{18: 1} \omega 12 t$. 
at $25{ }^{\circ} \mathrm{C}$. Optimal temperature for growth is $25{ }^{\circ} \mathrm{C}$. Growth occurs at 4 and $34{ }^{\circ} \mathrm{C}$, but not at $35^{\circ} \mathrm{C}$. Optimal pH for growth is between 6.5 and 7.0; growth occurs at $\mathrm{pH} 6.0$ and 9.5 , but not at $\mathrm{pH} 5.5$ or 10.0. Growth occurs in the presence of $0-1 \%(\mathrm{w} / \mathrm{v}) \mathrm{NaCl}$; optimal growth occurs without $\mathrm{NaCl}$. Anaerobic growth does not occur on NA or NA supplemented with nitrate. Tweens 20,40 and 60 are hydrolysed, but casein, hypoxanthine, xanthine and tyrosine are not. $\mathrm{H}_{2} \mathrm{~S}$ and indole are not produced. Lysine decarboxylase, ornithine decarboxylase and tryptophan deaminase are absent. In assays with the API ZYM system, alkaline phosphatase, esterase (C4), esterase lipase (C8), leucine arylamidase, trypsin, acid phosphatase and naphthol-AS-BI-phosphohydrolase are present, but lipase (C14), valine arylamidase, cystine arylamidase, $\alpha$-chymotrypsin, $\alpha$-galactosidase, $\beta$-glucuronidase, $\quad N$-acetyl- $\beta$ glucosaminidase, $\alpha$-mannosidase and $\alpha$-fucosidase are absent. Susceptible to polymyxin B, chloramphenicol, cephalothin, gentamicin, novobiocin, tetracycline, kanamycin and neomycin, but not to ampicillin, carbenicillin, lincomycin or oleandomycin. The predominant ubiquinone is Q-10. The major fatty acids $(>10 \%$ of total fatty acids) are $\mathrm{C}_{18: 1} \omega 7 c$ and $\mathrm{C}_{16: 0}$. Other phenotypic characteristics are given in Table 1 and Supplementary Table S1.

The type strain is DS- $18^{\mathrm{T}}\left(=\mathrm{KCTC} 12871^{\mathrm{T}}=\mathrm{JCM} 14602^{\mathrm{T}}\right)$, isolated from soil from Dokdo, Korea. The DNA G+C content of the type strain is $68.7 \mathrm{~mol} \%$ (determined by HPLC).

\section{Acknowledgements}

This work was supported by the 21C Frontier Program of Microbial Genomics and Applications (grant MG05-0401-2-0) from the Ministry of Science and Technology (MOST) of the Republic of Korea.

\section{References}

Abraham, W.-R., Strömpl, C., Meyer, H., Lindholst, S., Moore, E. R. B., Christ, R., Vancanneyt, M., Tindall, B. J., Bennasar, A. \& other authors (1999). Phylogeny and polyphasic taxonomy of Caulobacter species. Proposal of Maricaulis gen. nov. with Maricaulis maris (Poindexter) comb. nov. as the type species, and emended description of the genera Brevundimonas and Caulobacter. Int J Syst Bacteriol 49, 1053-1073.

Cowan, S. T. \& Steel, K. J. (1965). Manual for the Identification of Medical Bacteria. London: Cambridge University Press.

Ezaki, T., Hashimoto, Y. \& Yabuuchi, E. (1989). Fluorometric deoxyribonucleic acid-deoxyribonucleic acid hybridization in microdilution wells as an alternative to membrane filter hybridization in which radioisotopes are used to determine genetic relatedness among bacterial strains. Int J Syst Bacteriol 39, 224-229.

Fritz, I., Strömpl, C., Nikitin, D. I., Lysenko, A. M. \& Abraham, W.-R. (2005). Brevundimonas mediterranea sp. nov., a non-stalked species from the Mediterranean Sea. Int J Syst Evol Microbiol 55, 479-486.
Komagata, K. \& Suzuki, K. (1987). Lipid and cell-wall analysis in bacterial systematics. Methods Microbiol 19, 161-207.

Lanyi, B. (1987). Classical and rapid identification methods for medically important bacteria. Methods Microbiol 19, 1-67.

Li, Y., Kawamura, Y., Fujiwara, N., Naka, T., Liu, H., Huang, X., Kobayashi, K. \& Ezaki, T. (2004). Sphingomonas yabuuchiae sp. nov. and Brevundimonas nasdae sp. nov., isolated from the Russian space laboratory Mir. Int J Syst Evol Microbiol 54, 819-825.

Palleroni, N. J. (1984). Genus Pseudomonas Migula 1894. In Bergey's Manual of Systematic Bacteriology, vol. 1, pp. 141-199. Edited by N. R. Krieg \& J. G. Holt. Baltimore: Williams \& Wilkins.

Poindexter, J. S. (1964). Biological properties and classification of the Caulobacter group. Bacteriol Rev 28, 231-295.

Poindexter, J. S. (1989). Genus Caulobacter Henrici and Johnson 1935, 83 ${ }^{\mathrm{AL}}$. In Bergey's Manual of Systematic Bacteriology, vol. 3, pp. 1924-1939. Edited by J. T. Staley, M. P. Bryant, N. Pfennig \& J. G. Holt. Baltimore: Williams \& Wilkins.

Sasser, M. (1990). Identification of bacteria by gas chromatography of cellular fatty acids, Technical Note 101. Newark, DE: MIDI Inc.

Segers, P., Vancanneyt, M., Pot, B., Torck, U., Hoste, B., Dewettinck, D., Falsen, E., Kersters, K. \& De Vos, P. (1994). Classification of Pseudomonas diminuta Leifson and Hugh 1954 and Pseudomonas vesicularis Büsing, Döll, and Freytag 1953 in Brevundimonas gen. nov. as Brevundimonas diminuta comb. nov. and Brevundimonas vesicularis comb. nov., respectively. Int J Syst Bacteriol 44, 499-510.

Stackebrandt, E. \& Goebel, B. M. (1994). Taxonomic note: a place for DNA-DNA reassociation and 16S rRNA sequence analysis in the present species definition in bacteriology. Int J Syst Bacteriol 44, 846-849.

Tamaoka, J. \& Komagata, K. (1984). Determination of DNA base composition by reversed-phase high-performance liquid chromatography. FEMS Microbiol Lett 25, 125-128.

Urakami, T., Oyanagi, H., Araki, H., Suzuki, K.-I. \& Komagata, K. (1990). Recharacterization and emended description of the genus Mycoplana and description of two new species, Mycoplana ramosa and Mycoplana segnis. Int J Syst Bacteriol 40, 434-442.

Wayne, L. G., Brenner, D. J., Colwell, R. R., Grimont, P. A. D., Kandler, O., Krichevsky, M. I., Moore, L. H., Moore, W. E. C., Murray, R. G. E. \& other authors (1987). International Committee on Systematic Bacteriology. Report of the ad hoc committee on reconciliation of approaches to bacterial systematics. Int J Syst Bacteriol 37, 463-464.

Yoon, J.-H., Kim, H., Kim, S.-B., Kim, H.-J., Kim, W. Y., Lee, S. T., Goodfellow, M. \& Park, Y.-H. (1996). Identification of Saccharomonospora strains by the use of genomic DNA fragments and rRNA gene probes. Int J Syst Bacteriol 46, 502-505.

Yoon, J.-H., Lee, S. T. \& Park, Y.-H. (1998). Inter- and intraspecific phylogenetic analysis of the genus Nocardioides and related taxa based on 16S rRNA gene sequences. Int J Syst Bacteriol 48, 187-194.

Yoon, J.-H., Kang, K. H. \& Park, Y.-H. (2003). Psychrobacter jeotgali sp. nov., isolated from jeotgal, a traditional Korean fermented seafood. Int J Syst Evol Microbiol 53, 449-454.

Yoon, J.-H., Kang, S.-J., Oh, H. W., Lee, J.-S. \& Oh, T.-K. (2006a). Brevundimonas kwangchunensis sp. nov., isolated from an alkaline soil in Korea. Int J Syst Evol Microbiol 56, 613-617.

Yoon, J.-H., Kang, S.-J., Lee, J.-S. \& Oh, T.-K. (2006b). Brevundimonas terrae sp. nov., isolated from an alkaline soil in Korea. Int J Syst Evol Microbiol 56, 2915-2919. 